\title{
The effect of exercise on homocysteine and some blood parameters in middle-aged sedentary individuals
}

Nuri M. Çelik ${ }^{1 \mathrm{ABCDE}}$, Mehmet Soyal2ABCDE

${ }^{1}$ Batman University, Batman, Turkey

${ }^{2}$ Istanbul Gelisim University, Istanbul, Turkey

Authors' Contribution: A - Study design; B - Data collection; C - Statistical analysis; D - Manuscript Preparation; E - Funds Collection

\begin{tabular}{|c|c|}
\hline \multicolumn{2}{|l|}{ Abstract } \\
\hline Purpose: & $\begin{array}{l}\text { The objective of this study is to examine the effect of exercise on the blood levels of homocysteine, } \\
\text { hemoglobin and hematocrit in middle-aged sedentary individuals. }\end{array}$ \\
\hline Material: & $\begin{array}{l}\text { A total of } 24 \text { middle-aged (35-55 years) sedentary individuals ( } 12 \text { females and } 12 \text { males) living in Batman } \\
\text { province voluntarily participated in this study. Body weight, body mass index, Homocysteine, Hemoglobin } \\
\text { and Hematocrit blood levels were measured before and after a walking exercise scheduled for } 6 \text { weeks. } \\
\text { Walking exercise was administered } 4 \text { days a week for the } 6 \text { weeks. Initially, the walking exercises started } \\
\text { as } 40 \text { min and increased to } 60 \text { min towards the end of the program. In the exercises, walking tempo was } \\
\text { kept higher than normal and in parallel to the overall health levels of the subjects. The data obtained } \\
\text { were then analyzed through the SPSS } 25.00 \text { package program. }\end{array}$ \\
\hline Results: & $\begin{array}{l}\text { It was determined that there were statistically significant differences in the pretest and posttest } \\
\text { parameters of body weight, body mass index, and Homocysteine values. Additionally, it was determined } \\
\text { that, after the } 6 \text {-week exercise program applied to the female and male participants, there were } \\
\text { statistically significant differences between the pretest and posttest parameters of body weight, body } \\
\text { mass index, hematocrit, hemoglobin, and homocysteine blood levels. }\end{array}$ \\
\hline Conclusions: & $\begin{array}{l}\text { As the conclusion, it was determined that, after the } 6 \text {-week exercise program applied to a total of } 24 \\
\text { participants ( } 12 \text { females and } 12 \text { males), there were statistically significant changes in the values of body } \\
\text { weight, body mass index, hematocrit, hemoglobin, and homocysteine blood levels. It is suggested for } \\
\text { further studies to apply nutrition programs and exercise protocols on young people regularly doing } \\
\text { exercise and active athletes in different branches in order to contribute to sports science. }\end{array}$ \\
\hline Кеу & \\
\hline
\end{tabular}

\section{Introduction}

As is now globally accepted by everyone, exercise is an important factor in preventing many diseases. It is of vital significance that individuals, especially in the middle and advanced age groups, eat balanced and healthy foods in accordance with the age, exercise regularly and turn it into a lifestyle. Although this prevents many diseases, it may also cause some blood parameters to change depending on the type of the exercise.

Homocysteine (HCY) is a substance comprising of methionine, which is an amino acid taken by our bodies through the nutrients [1].

Methionine is found in foods that are rich in protein such as meat, eggs, fish and grains that we consume in order to sustain our daily lives. Homocysteine blood levels elevate in the middle and advanced age groups depending on many factors such as age, lifestyle, inadequateincorrect nutrition, vitamin deficiency (B6 B12 folate) or a lifestyle without exercise, which ultimately causes many diseases particularly vascular occlusion and stroke in our body.

Homocysteine (HCY) is an aminoacid containing sulfur obtained from the nutritional protein and is an intermediate product formed during methionine metabolism [2]. Elevated concentration of total $\mathrm{HCY}$

(c) Nuri M. Çelik, Mehmet Soyal, 2020

doi:10.15561/26649837.2020.0502 is an independent risk factor for atherosclerosis [2-6], cardiovascular diseases, stroke, and other thrombotic events [7-10].

Other vital factors affecting homocysteine include smoking, coffee, alcohol consumption and physical activity. It is reported that smoking, vegetable consumption, alcohol and coffee consumption have a strong relationship with plasma total HCY [11]. It was also explained that aerobic exercise lowers HCY levels compared to anaerobic exercise or a sedentary life [8].

Regular physical exercise is known to reduce the risk of developing cardiovascular diseases. It is also reported that the intensity and duration of exercise have different effects on plasma HCY levels today [5, 7].

Exercise is now a must in the world concerning the health. When it comes to living a healthy life or being a healthy individual, the treatments and pursuits in medicine are of course in the first place, followed by exercise and sports activities.

\section{Homocysteine Metabolism}

Homocysteine is an aminoacid, which is formed during methionine metabolism and which contains sulfur. Homocysteine has several forms in human plasma. They are bound to proteins, about $70-80 \%$ of which is mainly to albumin, by disulfide bonds. The rest of the homocysteine is oxidized, merging with dimers (homocysteine) or 
cysteine to form mixed disulfides. Homocysteine is free to exist in circulation in a very small proportion $(1 \%)$. Today, there are many techniques that can collectively measure different forms of homocysteine in plasma. With these methods, the measurement results are given as total homocysteine (HCY) [12].

The normal rate of HCY in the healthy population has been reported in several studies between 5-15 $\mu \mathrm{mol} / \mathrm{L}$ in hunger. This ratio is influenced by many factors, including being innate and acquired $[13,14]$.

In cases where methionine is surplus or Cysteine synthesis is required, homocysteine undergoes the trans-sulfuration. Here homocysteine combines with serine (an amino acid found in protein nutrients) to irreversibly form cystathionine through the enzyme cystathionine b-synthase, which is dependent on vitamin B6. Cystathionine is then hydrolyzed to cysteine. This is converted into glutathione or metabolized to sulfate at an advanced stage, ultimately being excreted in the urine [15].

Causes of Change of Homocysteine in the Body; Genetic Disorders in Metabolism

Homocysteine levels change as a result of genetic errors in human metabolism and nutritional deficiencies in cofactors such as vitamin B12, vitamin B6 and folate, which are essential for HCY metabolism. Homocysteine level is an important cardiovascular risk factor, and this factor is being affected from other factors as well. Other factors affecting homocysteine are age, gender, smoking, coffee, alcohol consumption and physical activity [16].

\section{Nutrition Disorders}

Deficiency of vitamin cofactors (BI2, B6 vitamins, folate) essential for homocysteine metabolism in the nutrition can cause hyperhomocysteinemia. Significantly elevated homocysteine concentrations were also observed in the dietary deficiency of the essential vitamin B12 cofactor and folate co-substrate [17]. There is a negative correlation among serum vitamin B12, folate, vitamin B6 concentrations and plasma homocysteine concentration in normal individuals [17]. It was suggested that approximately $2 / 3$ of patients with hyperhomocysteinemia were accompanied by a deficiency in one or more of the $\mathrm{B}$ vitamins. Although the addition of these to food normalizes the high level of homocysteine, it is not known whether this prevents cardiovascular mortality and morbidity.

\section{Other Causes}

Some diseases affect homocysteine metabolism. Plasma homocysteine concentration may rise 4 times above average as the creatine level elevates in patients with chronic renal failure [18]. Although plasma homocysteine levels often decrease after dialysis, it is difficult to show whether the increase in these patients is due to impaired metabolism or decreased excretion. The acceleration of atherosclerosis in renal failure in the terminal period can be partially explained by elevated plasma homocysteine concentration. In several publications, the relationship between hyperhomocysteinemia and hypothyroid was demonstrated, arguing that it has a role in increasing the frequency of vascular disease in patients [19]. Additionally, although it is known that the level of homocysteine varies by exercise, this change in homocysteine levels varies by the duration and intensity of exercise [20].

Long-lasting high-intensity exercises increase protein metabolism and alter blood concentrations of certain amino acids. The reduction of available methionine also increases the synthesis of novo methionine, decreasing the accumulation of HCY. If there is enough folate, vitamin B6, and vitamin B12 in the protein turnover mechanism, HCY concentrations decrease during high-intensity longlasting exercises. Contrary to this reaction, glycogen reserves are reduced by long-lasting exercises, which increases the necessity of vitamin B6-induced reactions. This results in an increase in the concentration of HCY with increased protein turnover during long-lasting exercise [21].

The fact that homocysteine levels are outside the normal limits will have many negative effects on our health. Knowing our homocysteine level, and if it is not within the normal limits, taking measures such as nutrition and exercise to balance this situation will protect us against homocysteine-related diseases. Some of these are serious diseases such as stroke and Alzheimer's, which are frequent in our age.

High concentration levels of homocysteine occur as a result of genetic errors in HCY metabolism and nutritional deficiencies in cofactors such as vitamin B12, vitamin B6 and folate, which are fundamental for HCY metabolism, and as a result of a lifestyle without exercise. Homocysteine levels are an important risk factor for cardiovascular diseases.

Previous studies demonstrated that regular physical exercise reduces the risk of cardiovascular diseases. However, when we examined the studies investigating the effects of physical activity on HCY [7, 8, 20, 22-24], it was also observed that the type, intensity and duration of exercise have different effects on HCY.

Hemoglobin is a compound found in red blood cells that transports oxygen from the lungs to skeletal muscles. Increased blood volume means that hemoglobin, which carries $\mathrm{O}_{2}$ to the metabolism, carries more oxygen to the body. Therefore, the volume of hemoglobin and blood is directly related to the amount of oxygen carried, and therefore, it also determines the volume of the aerobic or oxygen system. In an intensive and heavy exercise, the transport of oxygen to skeletal muscle cells significantly increases [25].

Hematocrit (HCT) part of the blood is generally increased as a result of long-term aerobic exercises. The reason for this is a small reduction in the serum portion of the blood as a result of increased fluid loss during exercise. Blood parameters affect the type and intensity of exercise, similarly, exercise affects the blood parameters and it is important concerning various blood pathologies [26].

During and after an intensive exercise, there may be changes in hematologic values due to differences such as training level of the individual, gender, age, environmental conditions and nutrition. Hematological changes are 
observed in athletes due to long-lasting exercises.

In athletes, who practice intensive exercise programs, the HGB and HCT values characteristically decrease, which is also described as athlete anemia [27, 28]. This is usually the case for measurements taken immediately after training.

There are many studies on how exercise affects hematological parameters. In fact, blood parameters affect the type and intensity of exercise, similarly exercise influences the blood parameters and it is important concerning various blood pathologies [29].

In the light of all this information, the aim of this study was to examine the changes in the blood levels of HCY, HCT and HGB during a 6-week regular exercise in the middle-aged group.

\section{Material and Methods}

Participants.

A total of 24 sedentary volunteers participated in the study, including 12 women with an average age of $43.58 \pm$ .94 years and 12 men with an average age of $46.08 \pm 6.82$ years. The average height of women was measured as 162 $\pm 4 \mathrm{~cm}$ and that of men was measured as $175 \pm 4.75 \mathrm{~cm}$. All participants were informed about the exercises and they were asked to sign an informed consent form before participating in the exercises.

Research Design.

Certain features of the participant individuals such as body weight, height, and BMI (Tanita, Body Composition Analyzer, SC-240 Tokyo Japan) were measured before the exercise program and blood samples were taken. Blood samples taken by a specialist nurse before and after the study program were analyzed in the Biochemistry Laboratory of Batman Regional State Hospital.

Exercise Protocol.

Participants were asked not to do any activity above normal level or take any medication prior to the tests. The exercise program was scheduled to last 6 weeks. Walking exercise was administered 4 days a week for the 6 weeks. Initially, the walking exercises started as $40 \mathrm{~min}$ and increased to $60 \mathrm{~min}$ towards the end of the program. In the exercises, walking tempo was kept higher than normal and in parallel to the overall health levels of the subjects. During the study, the subjects were not given a nutritional program.

Statistical Analysis.

The data obtained in the study were given as mean and standard deviation. Independent $t$ test was used for inter-group comparisons and Paired t test was used for comparison of intra-group pretests and posttests, and the significance level was accepted as $p<0.05$. SPSS 25 package program was used in the statistical analysis of the study.

\section{Results}

According to Table 1, the average age of the female participants was $43.58 \pm .94$ years and that of the male participants was $46.08 \pm 6.82$ years, while the mean height value of the women was $162 \pm 4 \mathrm{~cm}$ and that of men was $175 \pm 4.75 \mathrm{~cm}$.

According to Table 2, the pretests of males and females were compared and it was determined that there were statistically significant differences concerning the Body weight, Body mass index, and homocysteine

Table 1. Demographical information of the participants

\begin{tabular}{llllll}
\hline Variables & Gender & $\mathbf{N}$ & $\mathbf{X} \pm$ SD & min & max \\
\hline \multirow{2}{*}{ Age } & Female & 12 & $43.58 \pm 5.94$ & 35 & 53 \\
& Male & 12 & $46.08 \pm 6.82$ & 35 & 55 \\
Height & Female & 12 & $162 \pm 4$ & 156 & 170 \\
& Male & 12 & $175 \pm 4.75$ & 169 & 183 \\
\hline
\end{tabular}

Table 2. Comparison of the inter-group pretest values

\begin{tabular}{|c|c|c|c|c|c|}
\hline Variables & Groups & $\mathbf{n}$ & $\mathrm{X} \pm \mathrm{SD}$ & $\mathbf{t}$ & $\mathbf{p}$ \\
\hline \multirow{2}{*}{ Body weight } & Male & 12 & $91.08 \pm 5.55$ & \multirow{2}{*}{13.072} & \multirow{2}{*}{$0.01 *$} \\
\hline & Female & 12 & $67.66 \pm 2.77$ & & \\
\hline \multirow{2}{*}{ Body mass index } & Male & 12 & $29.52 \pm 1.55$ & \multirow{2}{*}{6.647} & \multirow{2}{*}{$0.41 *$} \\
\hline & Female & 12 & $25.70 \pm 1.24$ & & \\
\hline \multirow{2}{*}{ Homocysteine (HCY) } & Male & 12 & $32.59 \pm 4.41$ & \multirow{2}{*}{5.735} & \multirow{2}{*}{$0.02 *$} \\
\hline & Female & 12 & $24.57 \pm 1.97$ & & \\
\hline \multirow{2}{*}{ Hematocrit (HCT) } & Male & 12 & $43.54 \pm 2.55$ & \multirow{2}{*}{2.019} & \multirow{2}{*}{.056} \\
\hline & Female & 12 & $41.34 \pm 2.78$ & & \\
\hline \multirow{2}{*}{ Hemoglobin (HGB) } & Male & 12 & $13.51 \pm 1.08$ & \multirow{2}{*}{1.106} & \multirow{2}{*}{.281} \\
\hline & Female & 12 & $13.14 \pm .45$ & & \\
\hline
\end{tabular}

$* p<0.05$ 
(HCY) parameters $(\mathrm{p}<0.05)$, while there was statistically no significant difference in the other parameters $(\mathrm{p}>0.05)$.

According to Table 3, the posttests of males and females were compared and it was determined that there were statistically significant differences concerning the Body weight, Body mass index, and homocysteine (HCY1) parameters $(\mathrm{p}<0.05)$, while there was statistically no significant difference in other parameters $(\mathrm{p}>0.05)$.

According to Table 4, the pretest and posttest values of male participants were compared and it was determined that there were statistically significant differences concerning the Body weight, Body mass index, Homocysteine and Hemoglobin parameters at $\mathrm{p}<0.05$ level, while there was statistically significant difference in the Homocysteine parameter at $\mathrm{p}>0.05$ level.

According to Table 5, the pretest and posttest values of female participants were compared and it was determined that there were statistically significant differences concerning the Body weight, Body mass index, Homocysteine and Hemoglobin parameters at $p<0.05$ level, while there was statistically significant difference in the Homocysteine parameter at $\mathrm{p}>0.05$ level.

\section{Discussion}

In this study, changes in the blood levels of Homocysteine (HCY), Hemoglobin (HGB) and Hematocrit (HCT) were examined before and after a certain exercise program in middle-aged (35-55 years) sedentary individuals.

In the previous studies of the literature, a comparison was made between middle-aged individuals, who were doing exercise, and sedentary individuals, concluding that the HCY levels were lower in exercise-doing individuals compared to sedentary individuals [7].

In another study, 82 individuals were classified in 4 groups as sedentary, aerobic, anaerobic, and intermittent exercise groups. It was determined that the aerobic exercise group, where there was a high energy consumption, had lower HCY levels compared to sedentary and intermittent groups. A decrease was detected in the total HCY levels with aerobic exercise [30].

In a different study, it was determined that there were significant reductions in HCY levels in obese women after a 6-month walking program. In this study, we see that chronic aerobic exercise programs reduce the $\mathrm{HCY}$

Table 3. Comparison of inter-group posttest values

\begin{tabular}{|c|c|c|c|c|c|}
\hline Variables & Groups & $\mathbf{n}$ & $\mathrm{X} \pm \mathrm{SD}$ & $\mathbf{t}$ & $\mathbf{p}$ \\
\hline \multirow{2}{*}{ Body weight } & Male & 12 & $87.33 \pm 3.89$ & \multirow{2}{*}{15.530} & \multirow{2}{*}{$.000 * *$} \\
\hline & Female & 12 & $65.25 \pm 3.01$ & & \\
\hline \multirow{2}{*}{ Body mass index } & Male & 12 & $28.33 \pm 1.68$ & \multirow{2}{*}{5.690} & \multirow{2}{*}{$.000 * *$} \\
\hline & Female & 12 & $24.78 \pm 1.35$ & & \\
\hline \multirow{2}{*}{ Homocysteine (HCY) } & Male & 12 & $29.67 \pm 4.85$ & \multirow{2}{*}{4.979} & \multirow[t]{2}{*}{$.000 * *$} \\
\hline & Female & 12 & $22.29 \pm 1.68$ & & \\
\hline \multirow[t]{2}{*}{ Hematocrit (HCT) } & Male & 12 & $41.90 \pm 2.08$ & \multirow{2}{*}{1.666} & \multirow{2}{*}{.110} \\
\hline & Female & 12 & $40.20 \pm 2.85$ & & \\
\hline \multirow{3}{*}{ Hemoglobin (HGB) } & Male & 12 & $14.66 \pm 1.05$ & \multirow{3}{*}{1.075} & \multirow{3}{*}{.294} \\
\hline & & & & & \\
\hline & Female & 12 & $14.30 \pm .52$ & & \\
\hline
\end{tabular}

$* * p<0.001$

Table 4. Comparison of the pretest posttest values of the male participants

\begin{tabular}{|c|c|c|c|c|c|}
\hline Variables & Groups & $\mathbf{n}$ & $\mathrm{X} \pm \mathrm{SD}$ & $t$ & $p$ \\
\hline \multirow{2}{*}{ Body weight } & Male & 12 & $91.08 \pm 5.55$ & \multirow{2}{*}{3.469} & \multirow{2}{*}{$.005^{*}$} \\
\hline & Female & 12 & $87.33 \pm 3.89$ & & \\
\hline \multirow{2}{*}{ Body mass index } & Male & 12 & $29.52 \pm 1.55$ & \multirow{2}{*}{3.575} & \multirow{2}{*}{$.004 *$} \\
\hline & Female & 12 & $28.33 \pm 1.68$ & & \\
\hline \multirow{2}{*}{ Homocysteine (HCY) } & Male & 12 & $32.59 \pm 4.41$ & \multirow{2}{*}{7.380} & \multirow{2}{*}{$.000 * *$} \\
\hline & Female & 12 & $29.67 \pm 4.85$ & & \\
\hline \multirow{2}{*}{ Hematocrit (HCT) } & Male & 12 & $43.54 \pm 2.55$ & \multirow{2}{*}{3.320} & \multirow[t]{2}{*}{$.007 *$} \\
\hline & Female & 12 & $41.90 \pm 2.08$ & & \\
\hline \multirow{2}{*}{ Hemoglobin (HGB) } & Male & 12 & $13.51 \pm 1.08$ & \multirow{2}{*}{-3.372} & \multirow{2}{*}{$.006 *$} \\
\hline & Female & 12 & $14.66 \pm 1.05$ & & \\
\hline
\end{tabular}

${ }^{*} p<0.05 * * p<0.001$ 
Table 5. Comparison of the pretest posttest values of the female participants

\begin{tabular}{|c|c|c|c|c|c|}
\hline Variables & Groups & $\mathbf{n}$ & $\mathrm{X} \pm \mathrm{SD}$ & $\mathbf{t}$ & $\mathbf{p}$ \\
\hline \multirow{2}{*}{ Body weight } & Male & 12 & $67.66 \pm 2.77$ & \multirow{2}{*}{3.469} & \multirow{2}{*}{$.005^{*}$} \\
\hline & Female & 12 & $65.25 \pm 3.01$ & & \\
\hline \multirow{2}{*}{ Body mass index } & Male & 12 & $25.70 \pm 1.24$ & \multirow{2}{*}{3.575} & \multirow{2}{*}{$.004^{*}$} \\
\hline & Female & 12 & $24.78 \pm 1.35$ & & \\
\hline \multirow[b]{2}{*}{ Homocysteine (HCY) } & Male & 12 & $24.57 \pm 1.97$ & \multirow[b]{2}{*}{7.380} & \multirow[b]{2}{*}{$.000 * *$} \\
\hline & Female & 12 & $22.29 \pm 1.68$ & & \\
\hline \multirow{2}{*}{ Hematocrit (HCT) } & Male & 12 & $41.34 \pm 2.78$ & \multirow{2}{*}{3.320} & \multirow{2}{*}{$.007^{*}$} \\
\hline & Female & 12 & $40.20 \pm 2.85$ & & \\
\hline \multirow{2}{*}{ Hemoglobin (HGB) } & Male & 12 & $13.14 \pm .45$ & \multirow{2}{*}{-3.372} & \multirow{2}{*}{$.006 *$} \\
\hline & Female & 12 & $14.30 \pm .52$ & & \\
\hline
\end{tabular}

$* p<0.05 * * p<0.001$

blood levels [31].

In different research studies, women between the ages of 19-38 were divided into 3 groups and the first group was only administered creatine for 8 weeks, the second group was both applied resistance training and creatine, and the third group was given resistance training and placebo. Significant reductions were determined in plasma HCY levels in the second and third groups both of which underwent resistance training. In these two studies, it was observed that resistance exercises as well as aerobic exercises had positive effects on HCY [32].

In another study conducted by [20], it was found that total HCY levels were significantly lower in the physical activity group comprising of 118 middle-aged subjects. Furthermore, a significant inverse relationship was determined between plasma total HCY and aerobic physical capacity.

In a different research [33], it was stated that the 4-week exercise program in healthy men reduced the level of HCY, a different study [34] concluded that elevated plasma HCY levels in the increased risk of CVD in the elderly were partly related to lack of exercise.

Real et al. [22] determined a $19 \%$ elevation in postrace $\mathrm{HCY}$ levels of 26 professional and 26 amateur male athletes between the ages of 23-49. In another study [35], following a 6-month high intensity training, it was determined that there was an elevation in the post-training HCY levels of 327 healthy participants with an average age of 48.9 .

In a study conducted on healthy triathletes between the ages of 19-34 [23], an increase was detected in the HCY values.

In another research [8], it was observed in endurance athletes that there were moderate hyperhomocysteinemia, vitamin B12 deficiency, and low folate levels. In a study conducted by [36], no change was detected in HCY levels in the group performing an 8-week aerobic training with vitamin intake, while there was an increase, though not statistically significant, in HCY levels in the group performing the aerobic training with placebo intake.

In a different study [37], it was determined that there was no change in plasma HCY levels in 16 healthy sedentary male participants after a walking program 30 minutes each day at least 5 days a week for a total of 6 weeks.

Apart from long-term aerobic exercises [38], after a 6-month high and low intensity resistance trainings applied to 60-80 year-old healthy participants, it was determined that the serum HCY levels were lower than the control group following both resistance trainings.

In another study [24], the effects of acute exercise on plasma HCY levels were investigated on 20 physically active healthy men between the ages of 24-39. As a result of the study, it was determined that acute exercise did not affect plasma HCY levels in healthy men aged 24-39.

Moderate hyperhomocysteinemia can often occur among endurance athletes, accompanied by low levels of folate and vitamin B12. In a study conducted by [39], it was found that there was an increase in HCY levels in women after exercise in parallel to the menstrual cycle.

A different research [40] detected significant increases in hemoglobin values in subjects after an 8-week aerobic exercise. In a study conducted by [41], it was determined that there were significant increases in the hemoglobin levels of the subjects in an exercise program at $60-80 \%$ of max $\mathrm{VO}_{2}$. A different research [42] found a significant increase in hemoglobin levels in sedentary individuals after chronic exercise. Another study [43] conducted on adults aged 18-29 classified as normal and supplementary food groups, it was found that there were significant increases in hemoglobin levels in both groups as a result of an 8-week aerobic exercise. A different study [44] examined the chronic effects of extensive interval training on male athletes, determining significant increases in 
hemoglobin after an 8-week chronic exercise.

As a result of a study [45], in which 4 weeks of intensive training was applied after a 2-week normal training, it was determined that there were rhythmic and meaningless reductions in hemoglobin parameters at the first, second, and third weeks, while regular and significant increases were determined at the fourth, fifth, and sixth weeks.

In different previous studies, following an 8-week aerobic exercise [40], after 6 weeks of a moderate exercise on sedentary youth [46], and following acute exercise on men aged 32 years [47], the significant elevations were detected in HCT levels of the participants $(p<0.05)$. It was determined that there were significant increases in HCT values of 10 athletes following a 20-day chronic exercise [48].

In previous studies in the literature, it was determined that following a 20-day camp period for 25 athletes, no statistical changes were detected in HCT levels [49], a 6 -week high interval training did not produce an increase in HCT levels [50], or at the end of the 5-week training program for 16 male and 8 female judo athletes it was determined that there was a reduction in hematocrit values [51] $(\mathrm{p}<0.05)$.

In a study [52] conducted on 11 ( 7 males, 4 females) Olympic athletes, the blood samples of participants were taken after the season at high altitude, and it was found that, at high altitudes, there were significant increases in $\mathrm{HGB}, \mathrm{RBC}, \mathrm{HCT}, \mathrm{MCV}$ parameters. There were statistically no significant changes in WBC, PLT, $\mathrm{MCH}$ and MCHC parameters. Similarly, no significant differences were recorded in any parameters in the postseason measurements. In another research [53] conducted on marathoners, it was determined that, following the race, there were increases in erythrocyte count, hemoglobin, hematocrit, $\mathrm{MCH}$ blood levels and decreases in $\mathrm{MCV}$ levels compared to pre-race figures. In addition, reductions were detected in the erythrocyte count, hemoglobin and hematocrit levels after longer-term exercises such as the 20-day road race [54].

In another study, the subjects underwent a 2-hour running exercise that resulted in a $4 \%$ reduction in body weight, detecting a $12.2 \%$ reduction in plasma volume, a $6.3 \%$ reduction in erythrocytes, and a $9.6 \%$ reduction in blood volume. On the other hand, in some other studies no changes were determined in the volume of erythrocytes [55]. The ratio of hematocrit is around $42-50 \%$ in normal men, and around $37-47,1 \%$ in normal women [56].

In a different research, it was demonstrated that acute submaximal exercise significantly elevated erythrocyte, hematocrit (HCT), hemoglobin (HGB), leukocyte and platelet levels compared to pre-exercise values, concluding that these elevations are due to plasma losses caused by exercise. It was suggested that short-term exercise conducted until fatigue increases the number of leukocytes, and that this event cannot be explained only by the mechanism of hemoconcentration, and may also be related to metabolic changes that occur during the exercise [27].

Considering the studies in the literature, it is observed that the responses of blood values to exercise vary.

\section{Conclusions}

As a conclusion, examining homocysteine, hemoglobin, hematocrit and some other blood parameters of a total of 24 participants (12 men and 12 women), it was concluded that there were significant changes in HCY, HGB, HCT levels depending on the duration and intensity of the exercise. It is suggested for further studies to apply nutrition programs and exercise protocols on young people regularly doing exercise and active athletes in different branches in order to contribute to sports science.

\section{Conflict of interests}

The authors declare that there is no conflict of interests

\section{References}

1. Synevo Medical Laboratories Homocysteine-What is it. [Internet]. Synevo; 2015 May [cited 2020 Feb 1] [updated 2019 Jun 15; cited 2020 Feb 1]. Available from: https:// synevo.com.tr/tr/Homosistein-Nedir

2. Mayer EL, Jacobsen DW, Robinson K. Homocysteine and coronary athersclerosis. J Am Coll Cardiol. 1996; 27:517-527. https://doi.org/10.1016/0735-1097(95)00508-0

3. Hayward R, Ruangthai R, Karnilaw P, Chicco A, Strange R, McCarty $\mathrm{H}$, et al. Attenuation of homocysteine-induced endothelial dysfunction by exercise training. Pathophysiology, 2003;9:207-14. https://doi.org/10.1016/S0928-4680(03)00023-3

4. Selhub J. Homosisteine metabolism. Annu Rev Nutr. 1999; 19: 217- 246. https://doi.org/10.1146/annurev.nutr.19.1.217

5. Prerost MR, Feldman BF, Herbert WG. Homocysteine, Fibrinogen and physical activity in human males with coronary artery disease. Comparative Haematology International. 1999; 9: 25- 30. https://doi.org/10.1007/PL00010003
6. Lentz SR. Homocysteine and vascular dysfunction. Life Sciences. 1997; 61(13): 1205- 1215. https://doi.org/10.1016/S0024-3205(97)00392-5

7. Gaume V, Mougin F, Figard H, Simon-Rigaud ML, N'Guyen UN, Callier J, et al. Physical Training Decreases Total Plasma Homocysteine and Cysteine in MiddleAged Subjects. Ann Nutr Metab, 2005;49:125-31. https://doi.org/10.1159/000085536

8. Herrmann M, Schorr H, Obeid R, Urhausen A, Scharhag J, Kindermann W, Herrmann W. Homosisteine increases during endurance exercise. Clin Chem Lab Med. 2003; 41(11): 1518- 1524. https://doi.org/10.1515/CCLM.2003.233

9. Chambers JC, Obeid OA, Kooner JS. Physiological increments in plasma Homocysteine induce vascular endothelial dysfunction in normal human subjects. Arteriosclerosis and Thrombosis. 1999; 19: 2922-2927. https://doi.org/10.1161/01.ATV.19.12.2922

10.Mennen LI, de Courcy GP, Guilland J-C, Ducros V, Bertrais $\mathrm{S}$, Nicolas J-P, et al. Homocysteine, cardiovascular disease risk factors, and habitual diet in the French Supplementation 
with Antioxidant Vitamins and Minerals Study. The American Journal of Clinical Nutrition, 2002;76:1279-89. https://doi.org/10.1093/ajcn/76.6.1279

11.Bree A, Verschuren WMM, Blom HJ, Kromhout D. Lifstyle factors and plasma homocysteine concentrations in a general population sample. American Journal of Epidemiology. 2001; 154(2): 150-154. https://doi.org/10.1093/aje/154.2.150

12.Still RA, McDowell IF. ACP Broadsheet No 152: Clinical implications of plasma homocysteine measurement in cardiovascular disease. J Clin Pathol, 1998; 51:183-8. https://doi.org/10.1136/jcp.51.3.183

13.Frosst P, Blom HJ, Milos R, Goyette P, Sheppard CA, Matthews RG, et al. A candidate genetic risk factor for vascular disease: a common mutation in methylenetetrahydrofolate reductase. Nat Genet 1995;10:111-3. https://doi.org/10.1038/ng0595-111

14.Brattstrom L, Wilcken DE, Ohrvik J, Brudin L. Common methylenetetrahydrofolate reductase gene mutation leads to hyperhomocysteinemia but not to vascular disease: the result of a meta-analysis. Circulation, 1998;98:2520-6. https://doi.org/10.1161/01.CIR.98.23.2520

15.Finkelstein J D. The metabolism of homocysteine: pathways and regulation. E ur J Pediatr, 1998; 157 (suppl 2): S40-4. https://doi.org/10.1007/PL00014300

16.Panagiotakos DB, Pitsavos C, Zcimbckis A, Chrysohoou C, Stefanadis C. The association between lifestly-related factors and plasma homocysteine lebels in healthy individuals from the "ATTICA" study. International Journal of Cardiology. 2004;1: 1-7.

17.SelhubJ,JacquesPF,WilsonPW,RushD, RosenbergIH.Vitamin status and intake as in ary determinants of homocysteinemia in an elderly population. JAMA, 1993;270:2693-8. https://doi.org/10.1001/jama.1993.03510220049033

18.Savage DG, Lindenbaum J, Stabler SP, Alien RH. Sensitivity of serum methylmalonic acid and total homocysteine deterrninants for diagnosing cobalamin and folate deficiencies. Am I Med, 1994;96:239-46. https://doi.org/10.1016/0002-9343(94)90149-X

19.McCully KS. Homocysteine and vascular disease. Nat Med, 1996;2:386-9. https://doi.org/10.1038/nm0496-386

20.Unt E, Zilmer K, Mägi A, Kullisaar T, Kairane C, Zilmer M. Homocysteine status in former top-level male athletes: possible effect of physical activity and physical fitness. Scandinavian Journal of Medicine \& Science in Sports, 2008;18:360-6. https://doi.org/10.1111/j.1600-0838.2007.00674.x

21.Joubert LM, Manore MM. Exercise, nutrition, and homocysteine. International Journal of Sport Nutrition and Exercise Metabolism. 2006; 16: 341-361. https://doi.org/10.1123/ijsnem.16.4.341

22.Real JT, Merchante A, Gomez JL, Chaves FJ. Effects of marathon running on plasma total homocysteine concentrations. Nutr Metab Cardiovasc. 2005; 15: 134-139. https://doi.org/10.1016/j.numecd.2004.05.004

23.König D, Bissé E, Deibert P, Müller H-M, Wieland $\mathrm{H}$, Berg A. Influence of Training Volume and Acute Physical Exercise on the Homocysteine Levels in Endurance-Trained Men: Interactions with Plasma Folate and Vitamin $\mathrm{B}_{12}$. Ann Nutr Metab, 2003;47:114-8. https://doi.org/10.1159/000070032

24. Wright M, Francis K, Cornwell P. Effect of acute exercise on plasma homocysteine. J Sports Med Phys Fitness. 1998;38(3): 262-5.

25.Boone CH, Hoffman JR, Gonzalez AM, Jajtner AR, Townsend JR, Baker KM, et al. Changes in Plasma Aldosterone and
Electrolytes Following High-Volume and High-Intensity Resistance Exercise Protocols in Trained Men. Journal of Strength and Conditioning Research, 2016;30:1917-23. https://doi.org/10.1519/JSC.0000000000001276

26.Peçanha T, Paula-Ribeiro M, Campana-Rezende E, Bartels R, Marins JCB, de Lima JRP. Water Intake Accelerates Parasympathetic Reactivation After HighIntensity Exercise. International Journal of Sport Nutrition and Exercise Metabolism, 2014;24:489-96. https://doi.org/10.1123/ijsnem.2013-0122

27.Londeann R. Low heamatcrits during basic training athletes anemia. Nengld J Med, 1978;299: 1191-2. https://doi.org/10.1056/NEJM197811232992113

28.Thorner W. Quoted by srein hus AH. Choronic effects of exercise. Physiol Rew, 1933;24:622-4.

29.Çavuşoğlu H Egzersiz ve kan. Exercise and blood. İstanbul Tip Fakültesi 11. Kurultayl Bildiri Kitabl, 249 - 252., Istanbul Medical Faculty 11th Congress Proceedings Book, 1991. P.249 - 252. (In Turkish)

30.Rousseau AS, Robin S, Roussel AM, Ducros V, Margaritis I. Plasma homocysteine is related to folate intake but not training status. Nutrition Metabolism \& Cardiovascular Diseases. 2005; 15: 125-133. https://doi.org/10.1016/j.numecd.2005.02.002

31.Randeva HS, Lewandowski KC, Drzewoski J, BrookeWavell K, O'Callaghan C, Czupryniak L, et al. Exercise Decreases Plasma Total Homocysteine in Overweight Young Women with Polycystic Ovary Syndrome. The Journal of Clinical Endocrinology \& Metabolism, 2002;87:4496-501. https://doi.org/10.1210/jc.2001-012056

32.Steenge GR, Verhoef P, Greenhaff PL. The effect of creating and resistance training on plasma homocysteine concentration in healthy volunteers. Archives of Internal Medicine. 2001; 161: 1455-56. https://doi.org/10.1001/archinte.161.11.1455

33. Bailey DM, Davies B, Baker J. Training in hypoxia: modulation of metabolic and cardiovascular risk factors in men. Med Sci Sports Exerc. 2000; 32: 1058-1066. https://doi.org/10.1097/00005768-200006000-00004

34.Nygard O, Vollset SE, Refsum H, Stensvold I, Tverdal A, Nordrehaug JE, et al. Total plasma homocysteine and cardiovascular risk profile. The Hordaland Homocysteine Study. JAMA: The Journal of the American Medical Association, 1995;274:1526-33. https://doi.org/10.1001/jama.274.19.1526

35.Duncan G, Perri MG, Anton SD, Limacher MC, Martin D, Lowenthal DT, et al. Effects of exercise on emerging and traditional cardiovascular risk factors. Preventive Medicine, 2004;39:894-902. https://doi.org/10.1016/j.ypmed.2004.03.012

36.Dinç N. Aerobik egzersizin ve multivitamin kullanımının lipid, homosistein ve antioksidan metabolizmasl üzerine etkileri. Yüksek Lisans Tezi. [Effects of aerobic exercise and multivitamin use on lipid, homocysteine and antioxidant metabolism]. [Master Thesis]. Celal Bayar University, Institute of Health Sciences; 2006. (In Turkish)

37.Cooper A, Kendrick, A, Stansbie D, Sargent D. Plasma homocysteine in sedentary men: influence of moderately intense exercise. $C V R \& R$. 2000; 21: 371-74. https://doi.org/10.1097/00008483-200011000-00014

38.Vincent KR, Braith RW, Bottiglieri T, Heather K, Vincent HK, Lowenthal DT. Homocysteine and lipoprotein levels following resistance training in older adults. Preventive Cardiology. 2003; 6(4): 197-203. 
https://doi.org/10.1111/j.1520-037X.2003.01723.x

39.De Cree C, Malinow MR, Van Kranenburg GP, Geurten PG, Longford NT, Keizer HA. İnfluence of exercise and menstrual cycle phase on plasma homocysteine levels in young women a prospective study. Scand J Med Sci Sport. 1999; 9: 272-278. https://doi.org/10.1111/j.1600-0838.1999.tb00245.x

40.Ünal M. Aerobik ve anaerobik akut-kronik egzersizlerin immün parametreler üzerindeki etkileri [Effects of aerobic and anaerobic acute-chronic exercises on immune parameters]. Istanbul; 1998. (In Turkish)

41.FreundBJ,ShizuruEM,HashiroGM,ClaybaughJR.Hormonal, electrolyte, and renal responses to exercise are intensity dependent. Journal of Applied Physiology, 1991;70:900-6. https://doi.org/10.1152/jappl.1991.70.2.900

42.Nieman DC, Pedersen BK. Exercise And İmmune Function: Recent Development. Sports Med, 1999;27: 73-80. https://doi.org/10.2165/00007256-199927020-00001

43. Gallagher PM, Carrithers JA, Godard MP, Schulze KE, Trappe and SW. $\beta$-Hydroxy- $\beta$ Methylbutyrate İngestion, Part II: Effects on Hematology, Hepatic and Renal Function. Medicine and Science in Sports and Exercise, 2000;32:2116-9. https://doi.org/10.1097/00005768-200012000-00023

44.Büyükyazı G, Turgay F. Sürekli ve yaygın interval koşu egzersizlerinin bazı hematolojik parametreler üzerine akut ve kronik etkileri [Acute and chronic effects of continuous and widespread interval running exercises on some hematological parameters]. HU Sports Science. And Technic. School VI. Sports Research Congress Paper., 3-5 November, Ankara; 2000. P. 182. ( In Turkish)

45.Halson SL, Lancaster GI, Jeukendrup AE, Gleeson M. Immunological Responses to Overreaching in Cyclists. Medicine \& Science in Sports \& Exercise, 2003;35:854-61. https://doi.org/10.1249/01.MSS.0000064964.80040.E9

46.Ersöz G, Köksoy A, Zergeroğlu AM, Yavuzer S. Akut-Kronik Fiziksel egzersiz ve immunglobulinler. [Chronic Physical exercise and immunoglobulins]. Journal of Sports Sciences, 1995;6 (3): 3-12. (In Turkish)

47. Wade CE, Ramee SR, Hunt MM, While CJ. Hormonal and renal responses to converting enzyme inhibition during maximal exercise. J Appl Physiol, 1987;63: 1796-800. https://doi.org/10.1152/jappl.1987.63.5.1796

48.Patlar S. 4 haftalık kronik submaksimal egzersizin lökosit ve lökosit alt grupları üzerindeki etkisi. [The effect of 4-week chronic submaximal exercise on leukocyte and leukocyte subgroups]. 9th International Sports Sciences Congress, Mugla; 2006. P.226-227. (In Turkish)

49.Mashiko T, Umeda T, Nakaji S, Sugawara K. Effects of exercise on the physical condition ofcollege rugby players during summer training camp. Br j Sports Med, 2004;38: 186-190. https://doi.org/10.1136/bjsm.2002.004333

50.Gren HJ, Sutton JR, Coates G, Ali M, Jones S. Response of red cell and plasma volume to prolonged training in human. Journal of applied physiology, 1991;70(4): 1810-1815. https://doi.org/10.1152/jappl.1991.70.4.1810

51.Su YC, Lin CJ, Chen KT, Lee SM, Lin JS, Tsai CC, et al. Effects of huangqi jianzhong tang on hematological and biochemical parameters in judo athletes. Acta Pharmacol Sin. 2001;22: 1154-8.

52.Rietjens GJ, Kuipers H, Hartgens F, Keizer HA. Red blood cell profile of elite olympic distance triathletes. A threeyear follow-up. Int. J. Sports Med, 2002;23(6):391- 25. https://doi.org/10.1055/s-2008-1025634

53.Davidson RJL, Robertson JD, Gales $\mathrm{G}$ and Maughan RJ. Hematological changes associated with marathon running. Int. J. Sports Med. 1987;8:19-25. https://doi.org/10.1055/s-2008-1025634

54.Dressendorfer RH, Wadle $\mathrm{CE}$ and Amsterdam EA. Development of pseudoanemia in marathon runners during a 20-day road race. JAMA, 1981;246:1215-1218. https://doi.org/10.1001/jama.1981.03320110027020

55.Beamount W. Red cell volume with changes in plasma osmolarity during maximal exercise. Journal apply physiol, 1973;35: 47-50. https://doi.org/10.1152/jappl.1973.35.1.47

56.Berkarda B. Kan Hastalıklarl [Blood Diseases]. Istanbul; 2003. ( In Turkish)

\section{Information about the authors:}

Nuri M. Çelik; http://orcid.org/0000-0001-6403-6262; nmcelik42@hotmail.com; Batman University, School of Physical Education and Sports; Batman, Turkey.

Mehmet Soyal; (Corresponding author); http://orcid.org/0000-0001-6528-0275; mehmetsoyal3838@hotmail.com; Istanbul Gelisim University, School of Physical Education and Sports; Istanbul, Turkey.

Cite this article as:

Çelik N, Soyal M. The effect of exercise on homocysteine and some blood parameters in middle-aged sedentary individuals. Pedagogy of physical culture and sports, 2020;24(5):219-226.

https://doi.org/10.15561/26649837.2020.0502

This is an Open Access article distributed under the terms of the Creative Commons Attribution License, which permits unrestricted use, distribution, and reproduction in any medium, provided the original work is properly cited (http://creativecommons.org/licenses/by/4.0/deed.en).

Received: 26.02.2020

Accepted: 27.03.2020; Published: 30.10 .2020 